\title{
PENGEMBANGAN PELAYANAN DASAR PENDIDIKAN DI DESA BINYAN (DESA PILOT TAHUN 2018) MELALUI PENGINTEGRASIAN GERAKAN LITERASI SEKOLAH DALAM PEMBELAJARAN DAN PENGEMBANGAN POJOK LITERASI DI SD NEGERI 2 BUAHAN
}

\author{
I Wayan Numertayasa ${ }^{1)}$, Ni Ketut Desia Tristiantari²), I Putu Oka Suardana3) \\ 1)Program Studi Pend. Bahasa dan Sastra Indonesia, STKIP Suar Bangli, Bali, Indonesia \\ ${ }^{2}$ Program Studi Pend. Guru Sekolah Dasar, Fakultas Ilmu Sosial, Universitas Pendidikan Ganesha, Bali, Indonesia \\ 3)Program Studi Pend. Bahasa dan Sastra Indonesia, STKIP Suar Bangli, Bali, Indonesia \\ Corresponding author : I Wayan Numertayasa \\ E-mail : numertayasawayan@gmail.com
}

Diterima 12 November 2020, Direvisi 16 November 2020, Disetujui 16 November 2020

\begin{abstract}
ABSTRAK
Guru di SD Negeri 2 Buahan belum memiliki pemahaman yang baik terkait dengan pelaksanaan GLS di SD. Untuk mengatasi permasalah tersebut dilaksanakan PkM dengan mengembangkan pelayanan dasar Pendidikan di Desa Binyan melalui pengintegrasian GLS dalam pembelajaran dan pengembangan pojok literasi di SD Negeri 2 Buahan. PkM ini bertujuan untuk mengembangkan pelayanan dasar Pendidikan di Desa Binyan melalui pengintegrasian GLS dalam pembelajaran dan pengembangan pojok literasi di SD Negeri 2 Buahan. Adapun rancangan kegiatan yang digunakan adalah (1) identifikasi masalah; (2) Analisis Kebutuhan; (3) menyusun program, (4) pelaksanaan program, (5) evaluasi program, (6) tindaklanjut evaluasi, dan (7) pelaporan dan publikasi. Metode evaluasi program yang digunakan adalah metode observasi dan metode angket. Berdasarkan pelaksanaan rencana kegiatan, hasil yang diperoleh adalah (1) 9 orang guru SD Negeri 2 Buahan telah mampu mampu menyusun perencanaan dan melaksanakan literasi dalam pembelajaran. (2) Ada tujuh unit pojok literasi yang telah direalisasikan. (3) Kemampuan siswa meningkat dalam hal minat membaca.
\end{abstract}

Kata kunci: literasi; pembelajaran

\begin{abstract}
Teachers at SD Negeri 2 Buahan do not have a good understanding regarding the implementation of GLS in SD. To overcome this problem, PkM was implemented by developing basic education services in Binyan Village through integrating GLS in learning and developing literacy corners at SD Negeri 2 Buahan. This PkM aims to develop basic education services in Binyan Village through the integration of GLS in learning and the development of a literacy corner at SD Negeri 2 Buahan. The activity designs used were (1) problem identification; (2) Needs Analysis; (3) compiling programs, (4) implementing programs, (5) evaluating programs, (6) follow-up evaluations, and (7) reporting and publication. The program evaluation method used is the observation method and the questionnaire method. Based on the implementation of the activity plan, the results obtained were (1) 9 teachers of SD Negeri 2 Buahan were able to plan and implement literacy in learning. (2) There are seven literacy corner units that have been realized. (3) Students' abilities increase in reading interest.
\end{abstract}

Keywords : literacy; learning 


\section{PENDAHULUAN}

Desa Binyan sebagai Desa Pilot Tahun 2018 baru memiliki satu layanan pendidikan dasar yaitu SD Negeri 2 Buahan. Dalam upaya menghadapi revolusi industri 4.0 layanan Pendidikan memiliki peranan penting. Namun, peranan Pendidikan dalam menghadapi revolusi Industri 4.0 mengalami beberapa kendala. Menurut Risdianto, (2019) bidang pendidikan di indonesia adalah terdapat kendala antara lain belum meratanya infrastruktur, belum berubahnya mindset para pelaku khususnya para incumbent. Berdasarkan hal tersebut, keberadaan SD Negeri 2 Buahan diharapkan mampu memberikan layanan Pendidikan dasar di Desa Binyan. Untuk itu, keberadaan SD Negeri 2 Buahan sangat penting dalam rangka pembangunan di Desa Binyan. Namun, keberadaan SD Negeri 2 Buahan di Desa Binyan belum cukup memadai untuk menjadi layanan pendidikan dasar. Hal tersebut tercermin dari hasil observasi dan wawancara dengan kepala SD Negeri 2 Buahan berikut. (1) Jarak antara SD Negeri 2 Buahan dengan Kota Bangli adalah 45 KM. (2) SD Negeri 2 buahan memiliki guru sebanyak 9 orang, jumlah siswa 81 orang, dan memiliki rombel 6 kelas. (3) Ruang Kelas yang dimiliki sebanyak 7 kelas. (4) SD Negeri 2 Buahan tidak memiliki laboratorium dan perpustakaan. (5) SD Negeri 2 Buahan hanya memiliki 2 Sanitasi.

Berdasarkan data tersebut dapat dikatakan bahwa dilihat dari jarak pusat kota dengan lokasi SD Negeri 2 Buahan, lokasi SD Negeri 2 Buahan tergolong jauh sehingga untuk melakukan pengembangan sekolah agak terhambat dengan kendala jarak dan pemenuhan kebutuhan lainnya. Selanjutnya dari segi guru, SD Negeri 2 Buahan sudah memiliki guru sesuai dengan kebutuhan jumlah siswa. Lebih lanjut, ruang kelas yang dimiliki oleh SD Negeri 2 Buahan sudah cukup, hanya saja fasilitas yang ada di dalam ruang kelas masih perlu dikembangkan. Selanjutnya, fasilitas yang tidak dimiliki oleh SD 2 Buahan adalah laboratorium dan perpustakaan. Hal ini menunjukkan bahwa fasilitas untuk praktikum siswa belum memadai. Sumber bacaan pun dalam hal ini belum memadai karena SD Negeri 2 Buahan belum memiliki perpustakaan. Seperti yang kita ketahui bersama bahwa perpustakaan merupakan elemen yang sangat penting dalam pelaksanaan pendidikan sebagai wadah sumber belajar. Pendidikan tidak mungkin terselenggara dengan baik bilamana para tenaga kependidikan maupun siswa tidak didukung oleh sumber belajar yang diperlukan untuk penyelenggaraan kegiatan belajar mengajar yang bersangkutan (Juanda 2017) Berkaitan dengan pelaksanaan Pendidikan, salah satu kegiatan yang dicanangkan pemerintah melalui Kementrian Pendidikan dan Kebudayaan adalah Gerakan Literasi Sekolah (GLS). GLS merupakan sebuah upaya yang dilakukan secara menyeluruh untuk menjadikan sekolah sebagai organisasi pembelajaran yang warganya literat sepanjang hayat melalui pelibatan public (Faizah 2016:2). Hal terpenting dalam GLS adalah literasi. Menurut Faizah (2016:2) literasi dalam konteks GLS adalah kemampuan mengakses, memahami, dan menggunakan sesuatu secara cerdas melalui berbagai aktivitas, antara lain membaca, melihat, menyimak, menulis, dan/ atau berbicara. Berdasarkan kedua pandangan di atas dapat disimpulkan bahwa GLS merupakan upaya menjadikan sekolah sebagai organisasi pembelajaran untuk meningkatkan kemampuan mengakses, memahami, dan menggunakan sesuatu secara cerdas melalui berbagai aktivitas, antara lain membaca, melihat, menyimak, menulis, dan/ atau berbicara.

$$
\text { Adapun alasan pemerintah }
$$

menggalakkan program GLS adalah untuk meningkatkan keterampilan memahami, menggunakan, dan merefleksikan hasil membaca dalam bentuk tulisan SDM Indonesia. Wiedarti Hal ini perlu dilakukan karena data berikut ini (Wiedarti and Laksono 2016:i). PIRLS 2011 International Results in Reading, Indonesia menduduki peringkat ke-45 dari 48 negara peserta dengan skor 428 dari skor rata-rata 500 (IEA, 2012). Sementara itu, uji literasi membaca dalam PISA 2009 menunjukkan peserta didik Indonesia berada pada peringkat ke-57 dengan skor 396 (skor 
rata-rata OECD 493), sedangkan PISA 2012 menunjukkan peserta didik Indonesia berada pada peringkat ke-64 dengan skor 396 (skor rata-rata OECD 496) (OECD, 2013). Sebanyak 65 negara berpartisipasi dalam PISA 2009 dan 2012. Data PIRLS dan PISA, khususnya dalam keterampilan memahami bacaan, menunjukkan bahwa kompetensi peserta didik Indonesia tergolong rendah. Rendahnya keterampilan tersebut membuktikan bahwa proses pendidikan belum mengembangkan kompetensi dan minat peserta didik terhadap pengetahuan. Praktik pendidikan yang dilaksanakan di sekolah selama ini juga memperlihatkan bahwa sekolah belum berfungsi sebagai organisasi pembelajaran yang menjadikan semua warganya sebagai pembelajar sepanjang hayat. Untuk itu dilaksanakan GLS.

Kenyataan di atas juga dialami di SD Negeri 2 Buahan. Berdasarkan hasil observasi dan tes membaca dan menulis yang dilaksanakan di SD Negeri 2 Buahan didapatkan data bahwa kemampuan membaca dan menulis siswa di SD Negeri 2 Buahan masih tergolong rendah. Rendahnya kemampuan dasar membaca dan menulis menunjukkan hasil pelayanan pendidikan dasar di Desa Binyan masih tergolong rendah. Untuk itu, program GLS yang digalakkan pemerintah perlu dilaksanakan di SD Negeri 2 Buahan.

Berdasarkan hasil observasi awal dan wawancara dengan kepala SD Negeri 2 Buahan dapat dikatakan bahwa pelaksanaan GLS di SD Negeri 2 Buahan belum terlaksana dengan baik. Hal tersebut terlihat dari beberapa kendala yang dialami SD Negeri 2 Buahan. Pertama, Kendala yang dihadapi adalah berkaitan dengan fasilitas. Fasilitas yang dimaksud adalah fasilitas yang menunjang GLS. Dalam hal ini SD Negeri 2 Buahan belum memiliki bahan bacaan yang memadai. Kondisi ini dipersulit dengan kenyataan bahwa SD Negeri 2 Buahan belum memiliki perpustakaan. Padahal perpustakaan bisa menjadi alternatif pelaksanaan GLS di sekolah. Dalam hal ini literasi perpustaakan dapat melatih kemampuan memilih bahan pustaka yang sesuai jenjang dan minat secara mandiri dan dapat menambah pengetahuan siswa tentang bahan pustaka sebagai produk karya penulisan yang diciptakan melalui proses kreatif (Faizah 2016:48). Kedua, kendala yang dihadapi adalah guru belum mampu melaksanakan GLS sesuai dengan panduan yang dicanangkan oleh pemerintah melalui Kementrian Pendidikan dan Kebudayaan. Dalam hal ini guru masih kebingungan melaksanakan GLS di sekolah sehingga pelaksaan GLS menjadi tidak efektif. Menurut Faizah (2016:48) GLS di Sekolah Dasar dilaksanakan dalam tiga tahap, yaitu tahap pembiasaan, pengembangan, dan pembelajaran. Guru di SD Negeri 2 Buahan belum memiliki pemahaman yang baik terkait ketiga tahap tersebut. Ketiga, terkendala dengan implementasi kurikulum 2013. Kenyataan ini sesuai dengan hasil penelitian Suastika and Windari (2017) yang menyatakan bahwa sebagian besar guru Sekolah Dasar masih memeliki kelemahan dalam memahami tahapan Gerakan literasi sekolah.

Aturan baru yang dikeluarkan oleh Kementrian Pendidikan dan kebudayaan adalah seluruh sekolah pada tahun pelajaran 2018/2019 harus menerapkan kurikulum 2013 (https://edukasi.kompas.com > News > Edukasi, 30 Juni 2018). Aturan ini berdampak terhadap persiapan pelaksanan kurikulum 2013 di SD Negeri 2 Buahan. Guru lebih sering terlibat pelatihan implementasi kurikulum 2013 sehingga perencanaan dan pelaksanaan GLS tidak menjadi prioritas utama. Guru belum bisa mengatur dengan baik antara pelaksaaan GLS dan Implemetasi Kurikulum 2013 sehingga kedua kegiatan ini menjadi tidak efektif. Keempat, kendala selanjutnya adalah sebagain besar siswa yang ada di SD Negeri 2 Buahan berasal dari keluarga dengan tingkat ekonomi menengah ke bawah di Desa Buahan, Kecamatan Kintamani, Kabupaten Bangli. Kenyataan ini mengakibatkan orang tua tidak bisa memberikan dukungan terhadap GLS di SD Negeri 2 Buahan. Orang tua tidak bisa menyediakan bahan bacaan bagi anak mereka dirumah sehingga siswa tidak bisa mengimplementasikan GLS di rumah mereka masing-masing. 
Untuk mengatasi permasalahan yang diuraikan di atas perlu diadakan PkM kepada Masyarakat (PkM) dengan judul "Pengembangan Kegiatan Literasi Dalam Upaya Menghadap Revolusi IndusTRI 4.0 di SD Negeri 2 Buahan, Kintamani, Bangli"

Berdasarkan analisis situasi di atas diperoleh permasalahan mitra sebagai berikut. 1) Pelayanan Pendidikan Dasar di Desa Binyan belum memadai; 2) Sumber Daya Manusia dalam hal ini siswa di SD Negeri 2 Buahan memiliki kemampuan literasi yang masih tergolong rendah; 3) GLS di SD Negeri 2 Buahan belum didukung oleh fasilitas perpustakaan dan bahan bacaan yang memadai; 4) Kemampuan Guru di SD Negeri 2 Buahan dalam melaksanakan GLS masih digolongkan kurang baik; 5) Guru belum mampu melaksanakan GLS dan Kurikulum 2013 secara bersamaan; 6) Orang tua siswa di SD Negeri 2 Buahan belum mampu menyediakan bahan bacaan untuk menunjang GLS.

Berdasarkan uraian permasalahan di atas, solusi yang diberikan adalah Pelatihan dan Pendampingan metode gerakan Literasi Membaca dan Literasi Menulis dan penyediaan bacaan bacaan Literasi melalui pojok literasi di SD Negeri 2 Buahan di Desa Binyan .

Adapun solusi tersebut dijabarkan seperti berikut. 1) Pelatihan dan pendampingan literasi di SD negeri 2 Buahan melalui pengintegrasian GLS dalam pembelajaran dengan pendekatan active learning. 2) Penyediaan pojok literasi dengan buku Bermuatan Folklor Bali, buku bermuatan teks kearifan lokal Bali, dan majalah Si Kuncung.

\section{METODE}

Pelaksanaan Program Kemitraan Masyarakat (PKM) ini dilaksanakan di SD Negeri 2 Buahan, Kecamatan Kintamani, kabupaten Bangli. Pk Mini memerlukan integrasi terpadu beberapa pihak, seperti sekolah mitra (kepala sekolah, guru, pegawai, siswa) dan tim. Pelaksanaan program ini secara umum dilaksanakan dengan langkahlangkah berikut. (1) identifikasi masalah; (2) Analisis Kebutuhan; (3) menyusun program, (4) pelaksanaan program, (5) monitoring program, (6) evaluasi program, (7) tindaklanjut evaluasi, (8) penyebarluasan produk; dan (9) pelaporan dan publikasi. Berikut ini bagan langkahlangkah pelaksanaan Program Kemitraan Masyarakat (PKM) ini.

Berikut ini dijelaskan secara terperinci terkait dengan langkah-langkah Program Kemitraan Masyarakat (PKM) di atas.

Identifikasi Masalah

Pada tahap awal ini dilaksanakan tentang kendala pelayanan Pendidikan dasar di SD Negeri 2 Buahan, Desa Binyan dalam hal ini adalah kendala pelaksanaan Gerakan Literasi Sekolah. Kendala ada dua yaitu 1) kendala sumber daya manusia dalam hal ini kemampuan guru melaksanakan GLS dan sarana dalam hal ini sumber bacaan.

Analisis Kebutuhan

Pada tahap ini melakukan analisis kebutuhan untuk mengatasi permasalahan yang terjadi di sekolah mitra (pada tahap ini dilakukan perencanaan pelatihan dan pendampingan integrase GLS dalam pembelajaran serta rencana penyediaan pojok literasi)

\section{Menyusun Program}

Pada tahap ini dilaksanakan merancang pelatihan dan pendampingan GLS terintegrasi dalam pembelajaran dan merancang pojok literasi. Perancangan pelatihan dan pendampingan GLS terintegrasi dalam pembelajaran dan merancang pojok literasi melibatkan kepala sekolah, guru dan pegawai SD Negeri 2 Buahan serta tim PkM.

(a) Perencanaan pelatihan

Langkah-langkah yang dilaksanakan pada perencanaan pelatihan adalah terkait dengan materi pelatihan yang akan diberikan. Adapun materi yang akan diberikan adalah Pengintegrasian GLS dalam pembelajaran melalui pendekatan active learning. Submateri yang akan diberikan dalam pelatihan adalah 1) Gerakan Literasi Sekolah (GLS) di SD; 2) pendekatan active learning; (3) Rencana pelaksanaan GLS dengan pendekatan active learning . 
(b) Perencanaan pendampingan

Selanjutnya pada saat pendampingan

tim PkM mendampingi pelaksanaan Pengintegrasian GLS dalam pembelajaran melalui pendekatan active learning yang telah direncanakan pada saat pelatihan. Adapun pelaksanaan pendampingan meliputi pendampingan pada a) pelaksanaan literasi membaca dalam pembelajaran dengan pendekatan active learning; b) pelaksanaan literasi menulis dalam pembelajaran dengan pendekatan active learning; c) pemroduksian teks cerita flokor Bali atau teks cerita kearifan lokal Bali.

(c) Perencanaan pojok literasi

Berdasarkan observasi awal, SD Negeri 2 Buahan belum memiliki ruangan untuk perpustakaan. Berdasarkan keadaan ini Pojok Literasi akan direncanakan pada masingmasing kelas di SD Negeri 2 Buahan. Pada tahap ini tim merancang model pojok literasi yang menyesuaikan dengan keadaan kelas dan bahan bacaan yang disajikan adalah buku cerita flokor Bali, kumpulan teks cerita kearifan lokal Bali, dan Majalah Si Kuncung.

(d) Perencanaan produksi buku

Buku yang akan diproduksi dalam program ini adalah buku panduan pengintegrasian Strategi Literasi dalam Pembelajaran.

(e) Perencanaan penyebarluasan produk

Pada tahap ini, tim merencanakan penyebarluasan buku. Dalam hal ini direncanakan ISBN buku, jumlah buku yang akan disebarluaskan dan pihak-pihak yang akan menerima buku tersebut.

(f) Perencanaan publikasi

Pada tahap ini tim merencanakan publikasi hasil pelaksanaan program. Dalam hal ini ditentukan media tempat publikasi minimal di jurnal PkM masyarakat ber-ISSN.

(4) Pelaksanaan Program

Pada tahap ini kegiatan dilaksanakan sesuai dengan perencanaan yang telah dibuat oleh kepala sekolah dan pegawai di SD Negeri 2 Buahan dan tim PkM.

(5) Monitoring Program

Pada tahap ini dilakukan monitoring terhadap pelaksanaan program. Tim monitoring berasal dari Lembaga penelitian dan PkM Masyarakat (LPPM) STKIP Suar Bangli.

(6) Evaluasi Program

Evaluasi dilakukan terhadap pelaksanaan program yang telah dilaksanakan pada tahap sebelumnya. Selain itu, evaluasi dilaksanakan berdasarkan monitoring yang telah dilaksanakan pada tahap (5).

(7) Tindak lanjut evaluasi,

Selanjutnya setelah dilakukan evaluasi, tim PkM bersama dengan kepala sekolah dan pegawai SD Negeri 2 Buahan melakukan tindaklanjut dan perbaikan terkait program yang telah dilaksanakan. Dalam hal ini yang dilaksanakan adalah memperbaiki hasil pendampingan berupa keterampilan guru mengintegrasikan GLS dalam pembelajaran dengan pendekatan Active Learning dan Buku kumpulan cerita yang telah dihasilkan.

(8) Penyebarluasan produk;

Pada tahap ini, penyebarluasan produk dilaksanakan sesuai dengan rencana yang telah dirancang pada tahap sebelumnya.

(9) Pelaporan dan publikasi

Pada tahap ini dilaksanakan penyusunan laporan dan publikasi kegiatan yang telah dilakukan.

Evaluasi program menggunakan metode observasi dan metode angket, dalam hal ini yang dievaluasi adalah (1) kemampuan guru mengintegrasikan literasi dalam pembelajaran. (2) pojok literasi. (3) minat baca siswa.

\section{HASIL DAN PEMBAHASAN}

Kegiatan PkM ini dilaksanakan ke dalam 2 kegiatan utama yaitu (1) pelatihan; (2) pendampingan.

(1) Kegiatan Pelatihan

Kegiatan pelatihan ini dilaksanakan pada Senin, 29 Juli sampai dengan Rabu, 31 Juli 2019 (Gambar 1-3). Adapun materi pelatihan yang diberikan adalah a) Literasi di SD dan Strategi Literasi dalam Pembelajaran b) Implementasi Strategi Literasi dalam Perencanaan Pembelajaran dan Pelaksanaan Pembelajaran. c) Pojok Literasi.

Luaran yang dihasilkan dari pelatihan ini adalah pemahaman guru terhadap konsep 
integrasi strategi literasi dalam pembelajaran dan pemahaman konsep literasi dalam pembelajaran.

\section{(2) Kegiatan Pendampingan}

Pendampingan dilaksanakan pada dari 1 Agustus 2019 sampai dengan 30 Agustus 2019 dengan rincian: a) pendampingan menyusun perencanaan pembelajaran dilaksanakan pada 1 Agustus 2019 sampai dengan 3 Agustus 2019 (Gambar 4). b) pendampingan pelaksanaan pembelajaran dilaksanakan pada 5 Agustus sampai dengan 12 Agustus 2019 (Gambar 5). c) pendampingan pojok literasi dilaksanakan pada 19 Agustus sampai dengan 30 Agustus 2019 (Gambar 6).

Adapun luaran yang dihasilkan dari kegiatan pendampingan ini adalah a) guru mampu menyusun perencanaan pembelajaran dengan strategi literasi dan active learning. b) guru mampu melaksanakan pembelajaran dengan strategi literasi dan active learning. c) tersedianya pojok literasi yang menunjang pembelajaran siswa. d) minat membaca siswa meningkat.

Berikut ini disajikan dokumentasi kegiatan pelatihan dan pendampingan yang

dilaksanakan.

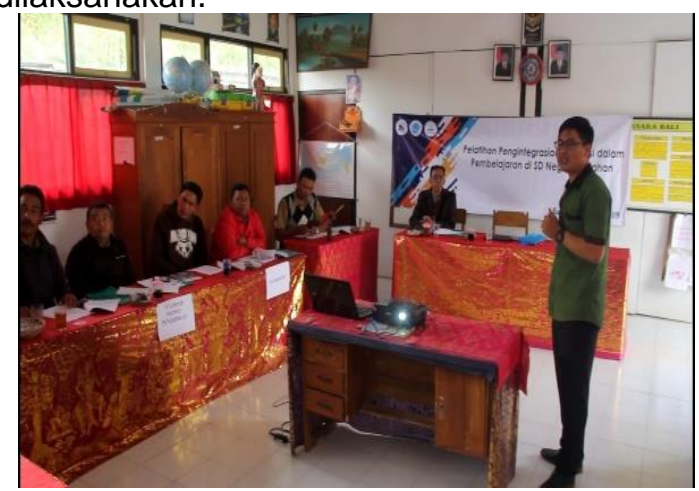

Gambar 1. Pelaksanaan Pelatihan pada 29 Juli 2019 dengan Materi Literasi di SD dan Strategi Literasi dalam Pembelajaran

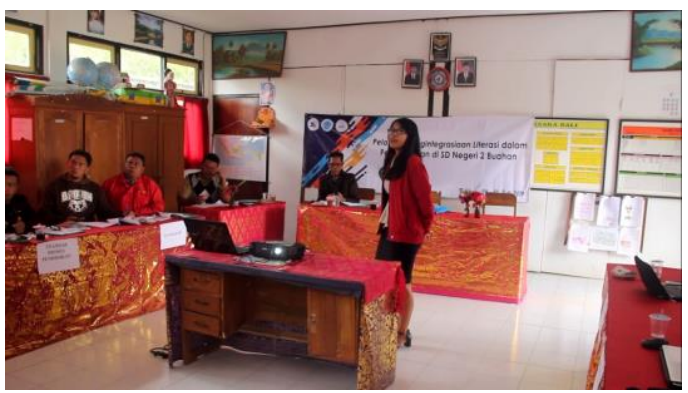

Gambar 2. Pelaksanaan Pelatihan pada 30 Juli 2019 dengan Materi Implementasi Strategi Literasi dalam Perencanaan Pembelajaran dan Pelaksanaan Pembelajaran.

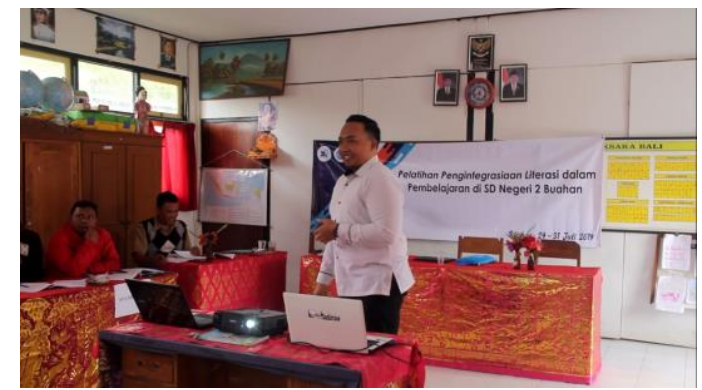

Gambar 3. Pelaksanaan Pelatihan pada 31 Juli 2019 dengan Materi Pojok Literasi.

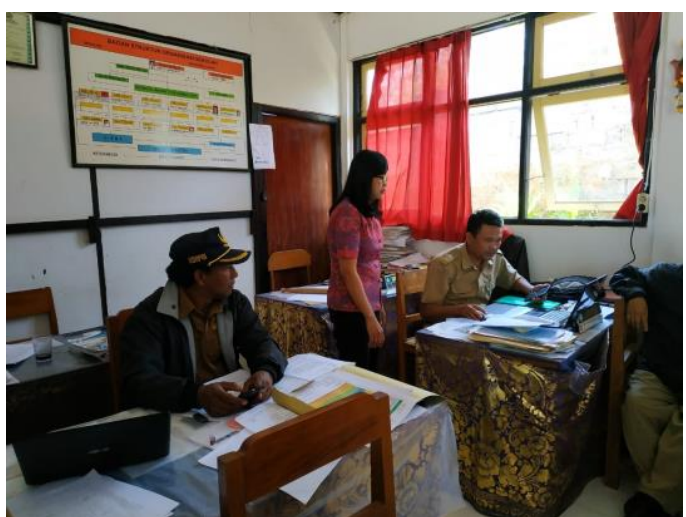

Gambar 4. Pelaksanaan Pendampingan Penyusunan Perencanaan Pembelajaran 


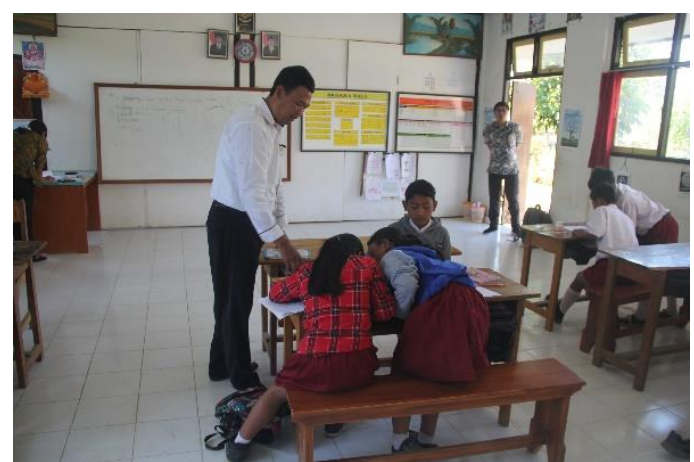

Gambar 5. Pelaksanaan Pendampingan Pelaksanaan Pembelajaran dengan Strategi Literasi

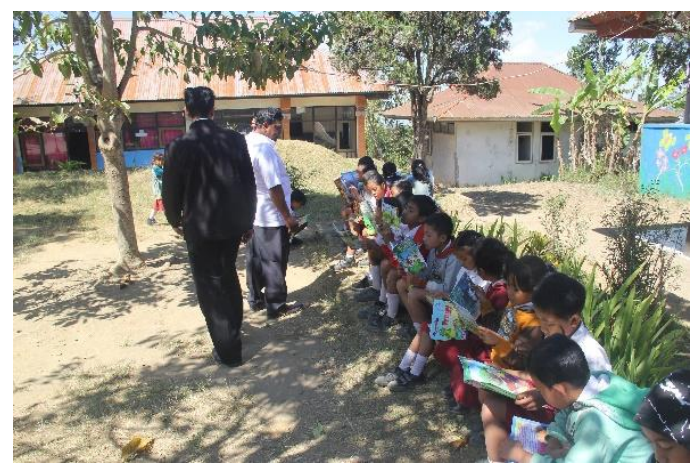

Gambar 6. Pendampingan membiasakan Siswa Membaca dari Bacaan yang Telah Disediakan di Pojok Literasi

Berdasarkan hasil pelaksanan PkM yang telah dilakukan berikut ini keunggulan dan kelemahan luaran yang dihasilkan.

Pertama, keunggulan kegiatan PkM ini adalah (1) guru memiliki pemahaman konsep yang baik tentang integrasi strategi literasi dalam pembelajaran. (2) guru mampu menyusun rencana pembelajaran yang terintegrasi strategi literasi dengan baik. (3) guru mampu mengimplementasikan strategi literasi dalam pembelajaran dengan baik. (4) Pojok literasi yang dikembangkan mampu meningkatkan minat baca siswa.

Kedua, adapun kelemahan kegiatan PkM yang telah dilakukan adalah (1) akses informasi bahan ajar baik cetak maupun daring untuk guru masih kurang. Dalam hal ini guru tidak memiliki sumber yang cukup untuk menyusun bahan ajar. (2) kemampuan membaca siswa secara keseluruhan di SD Negeri 2 Buahan masih rendah sehingga guru harus mengulang beberapa tema atau kompetensi dasar yang sama dalam melaksanakan pembelajaran.

Selain itu, kesulitan yang dihadapi dalam melaksanakan PkM ini adalah (1) akses jalan menuju SD Negeri 2 Buahan

cukup jauh dan terpencil, hal ini mengakibatkan guru dan siswa sering terlambat sampai di sekolah sehingga mempengaruhi waktu pelaksanaan kegiatan PkM. (2) Banyaknya kegiatan sekolah yang dilakukan, khususnya pada bulan Agustus. Hal ini mengakibatkan tim PkM beberapa kali melaksanakan penjadwalan ulang kegiatan. (3) cuaca di SD Negeri 2 Buahan tidak menentu. Hal ini mengakibatkan aktivitas kegiatan PkM menjadi terganggu.

\section{SIMPULAN}

Kegiatan PkM ini dilaksanakan di SD Negeri 2 Buahan dengan melaksanakan 2 kegiatan utama yaitu (1) pelatihan; (2) pendampingan. Hasil dari kegiatan PkM ini adalah (a) guru di SD N 2 Buahan memiliki pemahaman yang baik terhadap konsep integrasi strategi literasi dalam pembelajaran dan pemahaman konsep literasi dalam pembelajaran. (b) guru di SD N 2 Buahan mampu menyusun perencanaan pembelajaran dengan strategi literasi dan active learning. b) guru di SD N 2 Buahan mampu melaksanakan pembelajaran dengan strategi literasi dan active learning. c) tersedianya pojok literasi yang menunjang pembelajaran siswa. d) minat membaca siswa di SD N 2 Buahan meningkat.

\section{UCAPAN TERIMA KASIH}

Ucapan terima kasih disampaikan kepada bapak kepala SD negeri 2 Buahan Kintamani, Bangli. Berkat izin dan Kerjasama beliau PkM ini dapat diselesaikan tepat waktu. Selain itu, ucapan terima kasih disampaikan kepada guru dan siswa di SD negeri 2 Buahan Kintamani, Bangli atas kerjasamanya yang baik dalam menyukseskan kegiatan PkM ini. 


\section{DAFTAR RUJUKAN}

(https://edukasi.kompas.com > News > Edukasi, 30 Juni 2018).

(https://www.kemenkopmk.go.id/artikel/dari-37desa-program-desa-pmk-pilot-3diantaranya-sudah-mandiri).

Faizah, Dewi Utama. (2016). "Panduan Gerakan Literasi Sekolah Dasar.” Jakarta: Kemendikbud.

Juanda, Juanda. (2017). "Manfaat Perpustakaan Di Sekolah Dasar Bagi Kecerdasan Anak." Manfaat Perpustakaan Di Sekolah Dasar Bagi Kecerdasan Anak.

Risdianto, Eko. (2019). "Analisis Pendidikan Indonesia Di Era Revolusi Industri 4.0." Bengkulu: Universitas Bengkulu. Diakses Dari Https://Www. Researchgate. Net/Profile/Eko_Risdianto/Publication/33 2415017_ANALISIS_PENDIDIKAN_IND ONESIA_DIERA_REVOLUSI_INDUST RI_40/Links/5cb4509b4585156̄cd799351 9/ANALISIS-PENDIDIKAN-INDONESIADI-ERA-REVOLUSI-INDUSTRI-40. Pdf.

Suastika, I. Nengah, and Ratna Artha Windari. (2017). "MEMBERDAYAKAN GURUGURU SMP DAN SMA PGRI SERIRIT UNTUK MELAKSANAKAN MODEL PEMBELAJARAN BERBASIS KEARIFAN LOKAL SEBAGAI YADNYA DALAM RANGKA PENDIDIKAN KARAKTER BANGSA." WIDYA LAKSANA 4(2):14659.

Wiedarti, Pangesti, and Kisyani Laksono. (2016). Panduan Gerakan Literasi Sekolah Di Sekolah Dasar. 